\title{
The Importance of Localized Related Variety for International Diversification of Corporate Technology
}

Dettmann, Eva; Lacasa, Iciar Dominguez; Günther, Jutta; Jindra, Björn

\author{
Document Version \\ Accepted author manuscript \\ Published in: \\ Regional Studies \\ DOI: \\ $10.1080 / 00343404.2015 .1049994$ \\ Publication date: \\ 2016 \\ License \\ Unspecified
}

Citation for published version (APA):

Dettmann, E., Lacasa, I. D., Günther, J., \& Jindra, B. (2016). The Importance of Localized Related Variety for International Diversification of Corporate Technology. Regional Studies, 50(10), 1648-1662.

https://doi.org/10.1080/00343404.2015.1049994

Link to publication in CBS Research Portal

\section{General rights}

Copyright and moral rights for the publications made accessible in the public portal are retained by the authors and/or other copyright owners and it is a condition of accessing publications that users recognise and abide by the legal requirements associated with these rights.

\section{Take down policy}

If you believe that this document breaches copyright please contact us (research.lib@cbs.dk) providing details, and we will remove access to the work immediately and investigate your claim.

Download date: 26. Apr. 2023
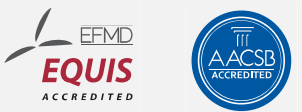


\section{The Importance of Localized Related Variety for International Diversification of Corporate Technology}

Eva Dettmann, Iciar Dominguez, Jutta Günther, and Björn Jindra Journal article (Post print version)

This is an Accepted Manuscript of an article published by Taylor \& Francis in Regional Studies on 08 Jul 2015: http://www.tandfonline.com/10.1080/00343404.2015.1049994

Uploaded to Research@CBS: December 2015 Available at Research@CBS 


\title{
The importance of localized related variety for international diversification of corporate technology
}

This paper was in a later version accepted for publication in Regional Studies.

\author{
EVA DETTMANN ${ }^{\dagger}$, ICIAR DOMINGUEZ LACASA $^{\ddagger}$, JUTTA GÜNTHER $^{{ }^{*}}$ and \\ BJÖRN JINDRA ${ }^{\ddagger \S}$
}

†Department of Structural Change and Productivity, Halle Institute for Economic Research (IWH), Kleine Märkerstrasse 8, Halle (Saale) D-06108, Germany.

‡Faculty of Business Studies and Economics, University of Bremen, Hochschulring 4, Bremen D-28359, Germany.

$\S$ Department of International Economics and Management, Copenhagen Business School, Solbjerg Plads 3, Frederiksberg DK-2000, Denmark. 
Abstract: Internationalization of research and development has increased substantially in Europe in recent years, and particularly in Germany. This paper analyses the determinants of spatial distribution of foreign technological activities across 96 German regions (1996-2009). The paper identifies foreign technological activities by applying the cross-border-ownership concept to patent applications. The main proposition of the paper is that regions with higher related variety of technological activities between sectors attract more foreign technological activities. The estimation of a pooled count data model shows that this is the case. However, it applies only to regions characterized by a high overall technological strength. This finding suggests that related variety facilitates technological diversifications of foreign corporations in regions at the top of the geographic hierarchy within host countries.

Keywords: multinational enterprises, R\&D, location, agglomeration, related variety

JEL classification: $\mathrm{F} 23, \mathrm{O} 32, \mathrm{O} 33, \mathrm{R} 12, \mathrm{R} 30$ 


\section{Introduction}

The internationalization of research and development (R\&D) has increased exponentially worldwide over the last two decades. Within the European Union (EU), Germany has attracted most technological activities by foreign firms in absolute terms since the 1970s (Cantwell and Piscitello, 2002). According to recent evidence Germany's share in the EU continued to grow (2001-2009), while the corresponding shares of the UK and France declined (IWH et al. 2013). Within the EU, Germany is also characterized by the highest cross-regional dispersion of foreign technological activities (Cantwell and lammarino, 2001; Cantwell and Noonan, 2002). Despite Germany's success in attracting foreign technological activities, the determinants of this particular sub-national dispersion received little attention so far.

This seems to be an important omission, since sub-national economic geography receives increasing attention in research on location behaviour of multinational enterprises (MNEs) (see for example McCann and Mudambi, 2005; McCann, 2011; Beugelsdijk and Mudambi, 2013). There is a recent surge in research on MNEs' sub-national location choice (Crozet et al., 2004; Barrios et al., 2006; Basile et al., 2008; Mariotti et al., 2010; Gauselmann and Marek, 2012; Marek 2012). In contrast, most empirical investigations on internationalization of corporate technology use a national level of analysis. These studies suggest that access to markets, R\&D and human capital in host countries are the main location drivers for foreign R\&D and innovation (see Hall, 2011 for an overview).

Yet the technological accumulation approach towards the growth of the MNE (Cantwell, 1989; 1995) suggests that the location of MNEs' technological activities depends upon the interrelationship between their corporate strategy and location specific characteristics. Drawing on the literature dealing with the spatial organization of R\&D (Malecki, 1985; Howells, 1990) as well as the geography of innovation (Feldman, 1994; Audretsch and Feldman, 1996), it is assumed that geographical proximity, localized knowledge spillovers, and agglomeration externalities are relevant factors to explain the location pattern of technological activities of MNEs.

Earlier research on MNEs' European R\&D networks suggests the existence of a geographical hierarchy of regional centres within and across countries (Cantwell, 2000; Cantwell and lammarino, 2001; 2003). The assumption is that regional agglomerations of knowledge attract foreign investors in technological activities to a different extent and with a different sectoral spread, depending upon the position of the region in the geographical hierarchy (Cantwell and lammarino, 1998; 2000). Only few studies (Cantwell and Piscitello, 2005; 2007) investigate the effect of spillovers and externalities on the location of foreign technological activities at the sub-national level directly. These studies concentrate on the role of Marshall-type externalities associated with the spatial concentration of technologically specialized firms, Jacobs-type urbanization economies associated with the co-presence of firm in different fields of research as well as science-technology spillovers. 
Drawing upon evolutionary economic thinking this paper contributes to the research on the spatial distribution of foreign technological activities by focusing on the role of related variety between sectors as source for location bound externalities. Recent contributions in evolutionary economic geography discuss the importance of cognitive proximity between actors for fruitful knowledge creation and interactive innovation processes (Boschma, 2005; Nooteboom, 2000). Related variety refers to the complementarity of capabilities of different sectors, which allows a recombination of knowledge and technology and supports economic development through interactive learning (Frenken et al., 2007). Applied to the regional context, one can assume that it is not only technological diversification or specialization in a region that matters per se for knowledge externalities, but the presence of a number of technologically related sectors in the sense of related variety (ibid).

The role of relatedness has also been considered in the literature on the interconnection between internationalization, technological diversification and competence creation at the firm level (Patel and Pavitt, 1997; 1998; Piscitello, 2000; Cantwell and Piscitello, 2000; 2014). Building upon the competence based theory (Richardson, 1972; Winter, 1988; Teece et al. 1994a; 1994b, Chandler et al., 1998), in which the firm is perceived as an institution that constructs internal learning processes in the form of evolutionary experimentation, it has been suggested that firms benefit from the dynamic economies of scope that derive from the technological complementarities between related fields of activities, and the complementarities between related paths of innovation or corporate learning in spatially distinct environments (Cantwell and Piscitello, 2000).

Therefore, we propose that related variety between sectors of a given region of a host country generates location bound externalities that contribute to explain the sub-national spatial distribution of foreign technological activities within a given host country. Whereas, a diversified but unrelated technological structure of a given region might offer important urbanisation economies and inter-industry spillovers, it is related variety of technological activities between sectors of a given region that should foster corporate technological diversification abroad. Using Patent Cooperation Treaty (PCT) applications as well as applications to the European Patent Office (EPO) with at least one German inventor, this paper adapts existing approaches (Breschi et al., 2003; Canter and Meder, 2009) to measure the degree of related variety of technological activities between sectors for 96 regions in Germany (1996-2009). Controlling for other sources of externalities and sector specific effects, we test whether the presence of technologically related sectors contributes to explaining the spatial dispersion of foreign technological activities within Germany. We identify foreign technological activities by applying the cross-border-ownership concept to the selected PCT and EPO patent applications.

The paper is structured in the following way: Section 2 provides the theoretical background. In section 3 we present the dataset and descriptive statistics. Section 4 introduces the econometric approach and the measures for agglomeration economies. Section 5 presents the estimation results. The final section presents the conclusions. 


\section{Theoretical background}

Theoretical approaches to economic geography explain the uneven distribution of economic activities in originally "neutral space". The emerging paradigm of evolutionary economic geography recombines theoretical and methodological concepts at the interface of neoclassical, institutional and evolutionary thinking (Boschma and Frenken, 2006; 2011), and thereby includes knowledge spillovers as an important factor in explaining regional development. In this sense, knowledge spillovers contribute to the self-reinforcing nature of agglomeration economies, i.e. firms in an industrially strong region stay there, attract additional firms, and thus contribute to synergy effects.

\section{1. "Traditional" sources of agglomeration economies}

Agglomeration economies are typically related to Marshall (1920) and refer to industrial or sectoral specialization. Such specialization externalities accrue not only to competitors, suppliers and customers in production activities but also to R\&D and innovation. A qualified workforce with experience in a certain field of research and specialized firms can constitute important inputs to the R\&D process (Saxenian, 1994). For this reason, an emerging specialized cluster of R\&D activities may provide important advantages to its members and thus sets in motion a self-reinforcing process that leads to strong spatial concentration (Verspagen and Scheonmakers, 2004). Against this background it has been suggested that a specialization advantage of a given region increases its attractiveness for foreign technological activities (Cantwell and Piscitello, 2005). In fact existing research shows that a revealed technological advantage of a region exerts a positive effect on the localization of foreign technological activities. However, such positive effects can be offset by competitive interaction, if specialization advantages are related to a dominant position of domestic firms or major international rivals of potential foreign entries (Cantwell and Piscitello, 2005; 2007; Cantwell and Santangelo, 2002; Alcacer and Chung 2007).

A second source of spillovers frequently included in empirical studies stems from the variety associated with the presence of firms from different sectors or industries. Such spillovers relate to diversity externalities which favour the creation of new ideas across sectors and emerged from the concept of "urbanisation economies" (Jacobs, 1969). Innovative firms may benefit from technological developments in industries other than their own (Devereux et al., 2007). This makes diversified regions attractive locations for foreign R\&D (Cantwell and Piscitello, 2005). The more diverse the technological activities within the region, the more firms can potentially benefit from it.

\subsection{The tacit dimension of knowledge}

Another explanation for the spatial concentration of technological activities is associated with the nature of knowledge. While information is fairly simple to codify, this is not the case with knowledge, owing to its tacit dimension (Cowan et al., 2000). According to Polanyi (1966), creative acts, and in particular acts of discovery depend crucially on personal feelings 
and commitment. Von Hippel (1994) argues that "sticky knowledge" cannot be transferred at insignificant cost.

Geographical distance hinders the exchange of tacit knowledge (Feldman, 1994; Audretsch and Feldman, 1996; Jaffe and Trajtenberg, 1996). Cantwell (1989; 1995) holds that technological knowledge is not perceived as an immediately usable intermediate input, but rather as an input into the collective learning process of the firm by which tacit competence is generated. Therefore, MNEs need to be on site with their own production and innovation activities if they are to benefit from the latest advances in geographically localized technological developments (Cantwell, 1989; Kogut and Chang, 1991).

\subsection{Science industry spillovers}

The efforts of firms to advance technology are not created in isolation, but are strongly supported by public research centres, universities, industry associations, an adequate education and science infrastructure (Kline and Rosenberg, 1986; Nelson, 1993; Rosenberg and Nelson, 1996; Nelson and Rosenberg, 1999; Breschi 2000).

The system of innovation approach (Edquist, 2005), originally developed as a theoretical concept at national level, has also been applied in the regional context, emphasizing the importance of spatial proximity if the synergy effects in the innovation process are to occur (Cooke, 1992; Asheim and Gertler, 2005). There is growing empirical evidence that such science-industry spillovers tend to be spatially bounded (Jaffe et al., 1993; Audretsch and Feldman, 1996; Cantner and Graf, 2006; Fritsch and Slavtchev, 2007). This could be especially true for multinational firms, which tend to have a greater degree of mobility when locating their corporate research, and so, for example, pay greater attention to being close to relevant public research facilities (Görg and Strobl, 2003). Cantwell and Piscitello (2005) find that R\&D employment in the public sector and the educational base within regions, as well as in adjacent regions, constitute significant pull factors for foreign technological activities.

\subsection{Related variety}

The seminal work of Glaeser et al. (1992) deals with an investigation of "Marshall" versus "Jacobs" hypotheses and provides evidence that knowledge spillovers are driven by diversification. It is important to note in the context of our research focus, that this form of region specific diversification does offer potential for inter-industry spillovers or urbanization economies, but it constitutes unrelated variety. Corresponding measures used in empirical research on the sub-national distribution of foreign technological activities do not account for the relatedness of activities between sectors of a given region.

Yet recent contributions in evolutionary economic geography discuss, apart from spatial proximity, the importance of cognitive proximity between actors for fruitful knowledge creation and interactive innovation processes (Boschma, 2005; Nooteboom, 2000). This means that creative interactions and knowledge flows are most likely to occur when actors 
are technologically neither too far apart nor too close. Applied to the regional context, one can assume that the presence of related industries is an important source of knowledge externalities, since a higher number of related industries, rather than simply different industries, increases the opportunities for interaction and knowledge flows (Frenken et al., 2007). Thus, related variety refers to the complementarity of capabilities of different sectors which allows a recombination of knowledge and technology and supports economic development through interactive learning (ibid). With the increased complexity of technology, the interaction between industries becomes more and more important, and in the light of evolutionary economic geography the interaction of technologically related industries is of considerable importance (Breschi et al., 2003; Frenken et al., 2007).

The concept of relatedness is also associated with earlier research on corporate diversification strategies, which was initially focused upon diversification into product markets related to firms' existing profiles of competencies (Piscitello, 2000), which facilitates the generation of economies of scale and scope (Chandler, 1990). Later this rationale was extended to the diversification of firms' technological competencies (e.g. Granstrand and Sjölander, 1992; Granstrand et al., 1997; Pavitt, 1999). Here it is suggested that firms do not diversify in a random way. A firm's engagement in technological fields does not change rapidly but is characterized rather by a degree of robustness (Teece et al. 1994a; 1994b).

Operating within environments of converging or increasingly interrelated technologies, large firms are seen to accumulate and maintain a much broader technological base thereby becoming multi technology corporations (Granstrand and Sjölander, 1992). It has been suggested that the association between corporate technological diversification and internationalization has been the outcome of more closely integrated MNE networks (Cantwell and Piscitello, 2000). International diversification of MNEs creates value through the development of internationally interdependent structures that connect a range of complementary activities (Cantwell, 2009). Thus, we would expect to observe diversification into related assets and the establishment of patterns of corporate coherence (Rumelt, 1974; Teece et al., 1994a;1994b, Piscitello, 2004). This perspective can be applied to corporate asset-seeking activities that become locally competence creating, in case MNEs are undertaking international investments as a means of developing new structures of relatedness between in-house activities (Cantwell, 2009).

In sum, these theoretical considerations would suggest that regions characterized by a high degree of technological related variety between sectors are more likely to attract foreign technological activities than others. So far only Cantwell and Noonan (2002) analysed the determinants of spatial distribution of foreign technological activities in Germany (1969 1995). They found limited evidence that localized specialization advantages, associated with domestic firms, attract foreign technological activities and suggest that interaction within regions primarily takes place mainly between actors in separate fields of specialization. The authors conclude that technology interaction between firms will only be demonstrated by acknowledging the role of technological complementarity (or relatedness) between sectors. This paper sets out to investigate this hypothesis. 


\section{Data and descriptive statistics}

We identify foreign technological activities by applying the "cross-border-ownership" approach to patent applications (Guellec und van Pottelsberghe de la Potterie, 2001; OECD, 2009). It assumes a case of internationalization if at least one inventor of a patent application resides in a country different from the applicant's country of residence. Since we focus on 'inward' foreign technological activities in Germany, this study is based on patent applications with at least one applicant residing abroad and at least one inventor located in Germany (FAGI). Although this approach does not allow to account for the ultimate corporate ownership of a patent application, it has been demonstrated that in most cases patents with a foreign applicant and a domestic inventor correspond to inventions created by local MNEs' research laboratories and applied for by the company headquarters located abroad (Guellec und van Pottelsberghe de la Potterie, 2004; OECD, 2009).

The cross-border-ownership approach has largely been applied in studies at country level (e.g. Guellec und van Pottelsberghe de la Potterie, 2004; Erken und Kleijn, 2010; Dachs und Pyka, 2011). To the best of our knowledge, this is the first application at a regional level of analysis by exploiting information on the sub-national location of the inventor. The sample is drawn from the OECD REGPAT Database (Edition January 2012) which allows a regionalization of the patent data. The sample is composed of Patent Cooperation Treaty (PCT) applications as well as applications to the European Patent Office (EPO) with at least one applicant located in a foreign country and at least one inventor located in one of the 96 German planning regions (RORs) ${ }^{1}$. Patent applications have a priority year between 1996 and 2009. The sample includes all PCT and EPO applications, which have not been transferred to the European phase of a PCT application to eliminate double counting (Frietsch et al., 2010). This way we identify patent families with at least one PCT or EPO application.

The key construct of our analysis - related variety - refers to the complementarity of capabilities of different sectors which allows a recombination of knowledge and technology (Frenken et al., 2007). Therefore, we need to identify technological activities within different sectors. The main barrier is that patent data are organised by technical characteristics according to the International Patent Classification (IPC) while economic data are categorised according to industry classification systems. To solve the matching problem different approaches have been developed (Verspagen et al. 1994; Kortum and Putnam, 1997; Johnson 2002; Schmoch et al. 2003; Lybber and Zolas 2014). We follow Schmoch et al (2003) whobuild a concordance between IPC and industrial sectors (NACE or ISIC) based on patenting activities of manufacturing firms. This way we reclassify the patent applications in our sample into 22 NACE (Rev. 1.1) 2-digit level industrial sectors. Lybber and Zolas (2014) review the different approaches and conclude that Schmoch et al. (2003) enables a concordance reliable for our level of aggregation of industries and for the time period we

\footnotetext{
${ }^{1}$ Planning regions (Raumordnungsregionen) are functional regional units based on commuting data. They are more suitable for spatial analysis of economic activities than purely administrative classification. The size of the planning regions is between NUTS2 and NUTS3 level.
} 
consider. As a result we can approximate total and foreign technological activities within 22 manufacturing sectors in 96 German regions. Moreover, this approach allows us to take account of other industry sector-specific variables in our analysis.

Now we turn to a first descriptive analysis of foreign technological activities in Germany during the observation period. The corresponding measure is the total number of patent applications with at least one foreign applicant and at least one German inventor (FAGI). We can show that this indicator more than doubled between 1996 and 2009 (see Table 1).

Table 1: $\quad$ Patent applications with at least one foreign applicant and at least one German inventor (FAGI) in Germany 1996 to 2009

\begin{tabular}{cccccc}
\hline Priority Year & FAGI total & FAGI min. & FAGI max & FAGI mean & $\begin{array}{c}\text { Variation } \\
\text { coefficient }\end{array}$ \\
\hline 1996 & 2089.23 & 0.00 & 178.26 & 21.76 & 1.66 \\
1997 & 2318.48 & 0.00 & 206.07 & 24.15 & 1.72 \\
1998 & 2946.92 & 0.00 & 295.97 & 30.70 & 1.77 \\
1999 & 3223.74 & 0.00 & 256.06 & 33.58 & 1.67 \\
2000 & 3603.69 & 0.50 & 261.52 & 37.54 & 1.54 \\
2001 & 3732.02 & 0.00 & 327.78 & 38.88 & 1.61 \\
2002 & 4007.80 & 0.00 & 415.34 & 41.75 & 1.63 \\
2003 & 4398.04 & 0.33 & 523.40 & 45.81 & 1.73 \\
2004 & 4469.72 & 0.00 & 467.37 & 46.56 & 1.58 \\
2005 & 4876.88 & 0.00 & 434.57 & 50.80 & 1.62 \\
2006 & 4736.27 & 0.00 & 398.48 & 49.34 & 1.54 \\
2007 & 5044.30 & 0.00 & 503.34 & 52.54 & 1.56 \\
2008 & 4682.97 & 0.00 & 456.08 & 48.78 & 1.58 \\
2009 & 4381.47 & 0.00 & 410.46 & 45.64 & 1.47 \\
\hline
\end{tabular}

Source: OECD REGPAT (Edition January 2012). Own calculations.

Over time, not only the total number of patent applications increased, but also the range between minimum and maximum values across all 96 planning regions in Germany. Together with the large, virtually stable variation coefficient, this points to a persistent heterogeneity of foreign technological activities across German regions.

Figure 1 presents a graphical presentation of the distribution of patent applications with at least one foreign applicant and at least one German inventor across the regions in the year 2009. Foreign technological activities seem to be concentrated in the southern and southwestern parts of Germany, in particular in Munich, Stuttgart, Rhine-Main and HochrheinBodensee. Each of these regions hosts more than 5 per cent of the total foreign technological activities in Germany (measured in terms of FAGI). Another eight regions in different geographic areas account for shares of between 2 and 5 per cent, and a further 12 regions have shares between 1 and 2 per cent. Each of the remaining 72 regions accounts for less than 1 per cent of total foreign technological activities.

Thus we find foreign technological activities to be spatially dispersed with a persistent pattern over time. Regions in the north and the east of Germany, with a few exceptions, account for comparatively little foreign technological activities. Most of the activities are concentrated in the highly industrialized southern and south-western regions of Germany. 
Figure 1: $\quad$ FAGI patent applications per planning region (ROR) in \% of total FAGI patent applications in Germany, 2009

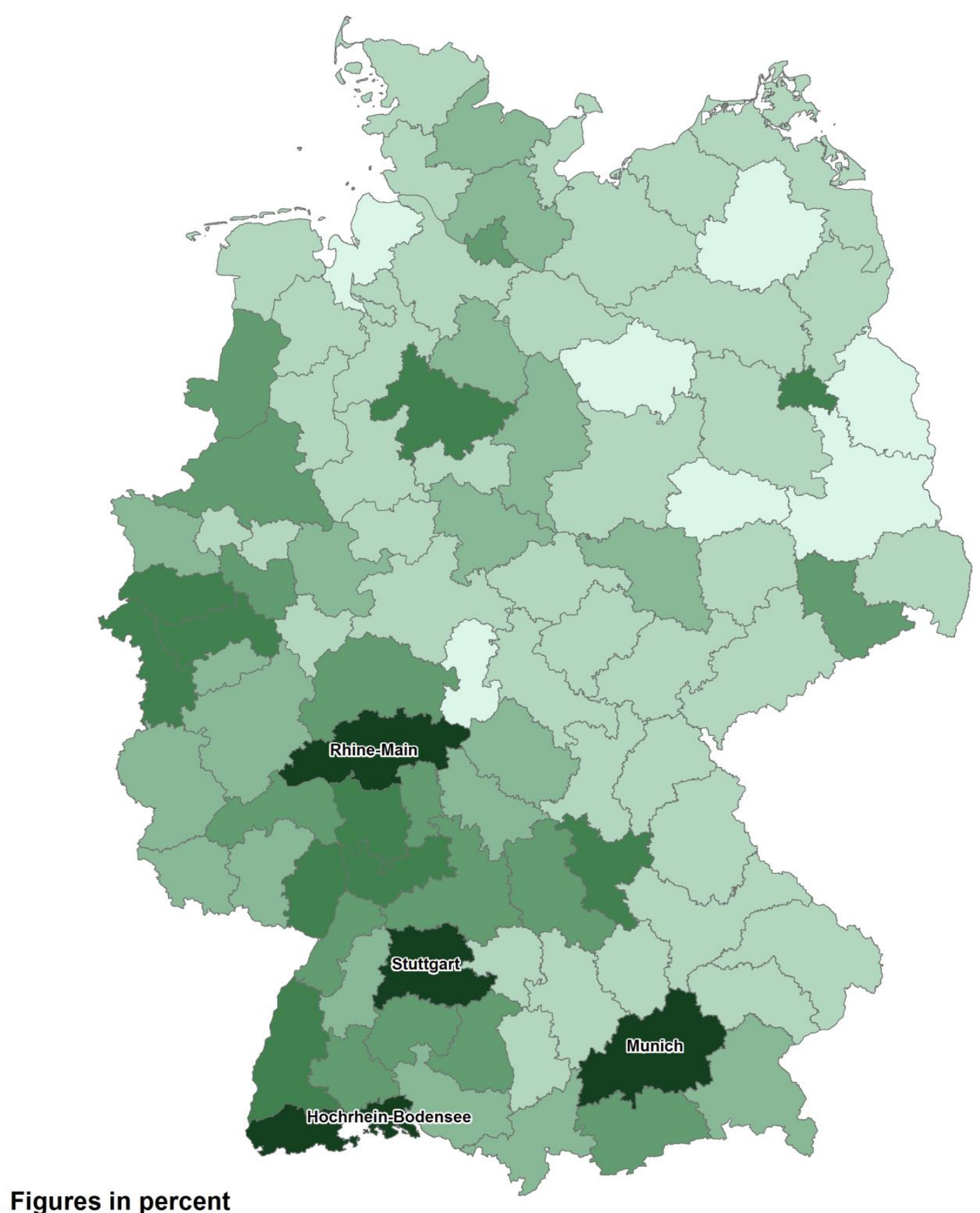

Figures in percent

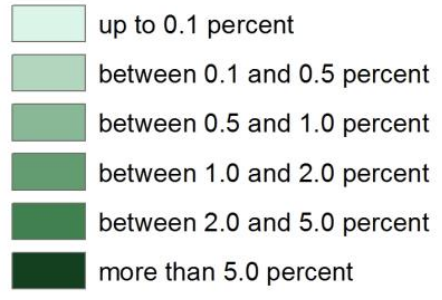

Source: OECD REGPAT (Edition January 2012). Own calculations. 


\section{Econometric approach}

\subsection{Specification of the econometric model}

Our dependent variable is defined as the annual number of patent applications with at least one foreign applicant and at least one German inventor for each of the 22 manufacturing sectors in each of the 96 planning regions in Germany (1996-2009). This corresponds to a total of 29,568 observations. In the process regional disaggregation we use fractional counts. In case there is more than one German inventor on a given patent application, and these inventors reside in separate German planning regions, we assign the patent application proportionally to the corresponding regions. Thus our dependent variable is a fractional count variable.

The frequency distribution of the dependent variable is extremely skewed to the left, suggesting the use of a count data model. This type of model assumes integer variables. For this reason, we need to transform fractional counts into integers by rounding up. This transformation increases the mean of the dependent variable (see Annex Table A1), which may result in an overestimation of the effect of the explanatory variables. In order to take this into account, it is necessary to restrict the interpretation of estimation results to the sign and the size of the coefficients instead of the coefficients themselves. ${ }^{2}$

Since the variance (43.42) of the transformed dependent variable substantially exceeds its mean (2.54) (see Annex Table A1), the econometric approach needs to account for the overdispersion. Therefore, a negative binomial regression model is used instead of the standard Poisson model. This model is an "extended" Poisson model that allows for individual unobserved effects and thus captures the source of over-dispersion (Winkelmann and Boes, 2006). A Voung test of excess zeros shows that no zero inflation of this model is necessary. ${ }^{3}$

In addressing the problem of endogeneity, different strategies are used to capture potential sources of the relationship between explanatory variables and the error term. ${ }^{4}$ Firstly, the pooled binomial model is estimated with robust standard errors allowing autocorrelation, relaxing the usual requirement of independence. ${ }^{5}$ Secondly, the explanatory variables enter the model with a time lag of one year. ${ }^{6}$

To mitigate the problem of potential spatial correlation a functional definition of regions is used instead of purely administratively defined units (Eckey et al., 2006). However, the problem might still occur. In fact, figure 1 indicates the existence of regional clusters of

\footnotetext{
${ }^{2}$ We estimate a tobit model for the unrounded data to check the robustness of our results (see Annex Table A4). The coefficients of the tobit model are similar, but (as expected) the model fit is rather poor.

${ }^{3}$ For coefficients of the zero inflated model and the test result see Annex Table A4.

${ }^{4}$ An alternative to address endogeneity is to use instruments for the potentially endogenous variables. Yet we could not find a strong instrument in the available dataset. In addition, the problem might not be limited to one covariate only, which would make it necessary to find instruments for all key variables.

${ }^{5}$ Another way of capturing the influence of omitted variables is to apply a fixed effects panel model (Allison 2009). As a robustness check, we estimate a fixed effects binomial regression model (see Annex Table A4).

${ }^{6}$ Variation in the lag structure leads to similar coefficients (see results of 5-year lag in Annex Table A4).
} 
foreign technological activities - or potential spatial correlations between neighbouring regions. The results of the Morans I tests also point to spatial autocorrelation of the dependent variable (see Annex Table A2). However, the coefficient of Morans I is always close to zero, indicating that spatial dependency is very weak. Nevertheless, spatial lags of our key explanatory variables are included in all specifications.

In addition, a nonlinearity of the influence of technological specialization on the dependent variable was found. Presumably, the relevance of externalities related to technological specialization varies depending on the R\&D intensity of the sector in question (Castells and Hall, 1994; Almeida and Kogut, 1997). In order to capture this influence, an interaction term is included consisting of a dummy for high-tech manufacturing sectors ${ }^{7}$ and specialization on the basis of the number of patents.

The pooled binomial regression model can be expressed as follows:

$$
F A G I_{i j t}=\exp \left(X_{i j t-1} \beta+\varepsilon_{i j}\right) \text {. }
$$

FAGI denotes the number of patent applications with at least one applicant located abroad and at least one inventor located in Germany in region $i$ and sector $j$ over the time period 1996 to 2009, where $i=1, \ldots, 96$ regions and $j=, 15, \ldots, 36$, the NACE code of the 22 manufacturing sectors. Vector $X$ contains the explanatory variables described below; $B$ denotes the coefficients vector and $\varepsilon$ the individual error term.

Vector $X$ in our model specification (1) contains agglomeration measures for sectoral specialization of technological activities, diversification of technological activities across sectors and the science and education infrastructure as key explanatory variables. In specification (2) and (3) we add measures for related variety of technological activities between sectors instead of diversification measure (see chapter 4.2 below for definition of all agglomeration indices used in this analysis).

We further control in all specifications for the cumulative number of prior patent applications with at least one German inventor to capture the path-dependent and cumulative nature of technological activities. Furthermore, we use a set of control variables commonly applied in the literature of multinationals' sub-national location choice (Crozet et al., 2004; Barrios et al., 2006; Basile et al., 2008; Mariotti et al., 2010 etc.), which includes: the share of highly qualified employees as a proxy for sector specific human capital, the business tax rate as a proxy for regional location costs, the quality of transport infrastructure measured as journey time to the next motorway, an index of the quality of healthcare system as a proxy for quality of life, the size of the region, and a dummy for regions that host the capital of the federal state. ${ }^{8}$ Finally, dummies for sector, year and federal state are included. The error term $\varepsilon$ captures individual unobserved heterogeneity.

\footnotetext{
${ }^{7}$ The definition of high-tech sectors corresponds to the OECD classification (Hatzichronoglou 1997).

${ }^{8}$ For a detailed overview of variables and operationalization see Annex Table A3.
} 


\subsection{Measures for agglomeration economies}

In order to capture sector specific specialization externalities of technological activity, we use the revealed technological advantage index (RTA), a concept developed first for the country level (Soete, 1987) and later adapted to company patterns (Cantwell, 1989; Patel and Pavitt, 1991). It measures the relative specialization of a region in terms of the relation between the sectoral output in a specific region and the output of this region in general. It controls for inter-sectoral and inter-regional differences in the propensity to patent. In our case the RTA index is calculated on the basis of the number of patent applications with at least of German inventor for each year. The RTA index can be written as follows:

$$
\operatorname{RTA}_{i j t}=\frac{P_{i j t} / \sum_{i} P_{i j t}}{\sum_{j} P_{i j t} / \sum_{i j} P_{i j t}} .
$$

$P$ denotes the number of all patent applications with at least one German inventor. The indices denote the sector $(i)$, region $(j)$ and year $(t)$. Values of $R T A>1$ suggest that a region is comparatively specialized in a sector of activity in question relative to other regions, whereas values of $R T A<1$ are indicative of a position of comparative disadvantage.

Following Basile et al. (2012), this paper uses the median location quotient (MLQ) as a measure of externalities related to diversification of technological activities across sectors of a region. The MLQ can be written as follows:

$$
M L Q_{i t}=\frac{L Q_{i t, J / 2}+L Q_{i t, J / 2+1}}{2} \text { with } L Q_{i j t}=\frac{P_{i j t} / \sum_{j} P_{i j t}}{\sum_{i} P_{i j t} / \sum_{i j} P_{i j t}}
$$

where $M L Q$ is the regional median of location quotient $L Q$ over the manufacturing sectors $(J=22)$. The location quotient is calculated on the basis of the number of patent applications with at least one German inventor $P$ in sector $i$ and region $j$ in year $t$. It expresses the relation between the regional output in a specific sector and the output of this sector in general. Contrary to RTA, it gives an impression on the importance of a region for a special sector. The median $M L Q_{i t}$ is a measure of the number of sectors for which a region plays an important role: a high median indicates that a region has a comparative advantage in a large number of sectors, and is therefore diversified, whereas a low median means that a region is not diversified.

It is important to note that the indices of specialization and diversification follow different concepts. Whereas the RTA index relies on Marshall's theoretical consideration of intraindustry externalities, the MLQ index follows the Jacob's concept of inter-industry externalities. A high RTA means that a sector within a region is specialized relative to other regions, whereas, a high MLQ indicates that a region has a comparative advantage in a large number of sectors, and therefore is diversified. 
We adapt an existing approach to measure externalities of related variety, which considers relatedness to be an ex ante phenomenon and points to the underlying scientific or engineering principles as indicating the degree of relatedness between technological activities (Breschi et al., 2003). This approach has already been used to capture sub-national patterns of technological relatedness (Cantner and Meder, 2009). Building upon this approach, we first identify technological activities within different sectors of a region by employing the concordance between International Patent Classification, technological fields and industrial sectors (see section 3 for a more detailed discussion). Second, we count for all possible pairs of manufacturing sectors, the joint occurrences as indicated in the patent documentation. For this step, we use all available patent information, i.e. information on all patents with at least one German inventor for the whole observation period (1996-2009). The information is summarized in a symmetrical co-occurrence matrix. Third calculating the cosine index of all elements of the matrix, results in a sector specific measure of similarity that is independent of the absolute size of a sector, the matrix of knowledge relatedness $\mathrm{S}{ }^{9}$

$$
S=\left(\begin{array}{ccc}
s_{11} & \ldots & s_{1 J} \\
\vdots & \ddots & \vdots \\
s_{J 1} & \cdots & s_{J J}
\end{array}\right) \text { with elements } s_{j k}=\frac{\sum_{x=1}^{22} c_{j x} c_{k x}}{\left(\sqrt{\sum_{x=1}^{22} c_{j x}^{2}}\right) \sqrt{\sum_{x=1}^{22} c_{k x}^{2}}}
$$

The elements $s_{j k}$ of the matrix express the similarity of two sectors in terms of their mutual relationship with all other sectors; $c_{j k}$ denotes the number of patents classified in both sectors $j$ and $k$.

In the next step an index is generated that expresses the relatedness of technological activities between sectors at regional level. For this, the joint share of patenting activities for all possible pairs of sectors per region and year is identified. This regional co-occurrence is combined with the general knowledge relatedness by element-wise multiplication of both matrices. Summing up all elements of the resulting matrices, one obtains the regional specific related variety (RRV):

$$
R R V_{i t}=\sum_{j=1}^{22} \sum_{k=1}^{22} \frac{p_{i j t} * p_{i k t}}{p_{i t}} * s_{j k}
$$

The RRV index is a measure of the strength of relatedness of technological activities between the sectors within a region. It does not, however, take into account the underlying size of the

\footnotetext{
${ }^{9}$ Relatedness of technological activities between sectors could be viewed as an 'absolute' characteristic independent of location. Therefore, ideally the general relatedness matrix should be measured using a European or worldwide patent applications. However, in an attempt to calculate corresponding matrices we encountered computational limitations. As an alternative approach, we computed relatedness matrices for Great Britain, Italy and France as other European economies that attract most foreign technology. We compared these to the German relatedness matrix and we found relatively small deviations in the relatedness indices between selected sector pairs. The overall pattern of relatedness of technological activities between sectors seems to be very similar across the selected countries. Given that we are interested in the spatial variance of relatedness of technological activities between sectors within Germany, we use all patent applications with at least one German inventor as a basis for calculating the general relatedness index.
} 
technological activities within the region itself. In our sample we have a number of German regions that show overall very low technological activity. If overall patenting activity is concentrated in two sectors of a given region, which are also characterised by high relatedness, this leads to comparatively high RRV index values, despite very low overall technological activity within the region. Therefore, a second regional relatedness measure is generated by multiplying the RRV index by the number of patent applications with at least one German inventor within the region:

$$
Q K B_{i t}=\ln \left(p_{i t}\right) * R R V_{i t}
$$

This 'quality of knowledge base index' (QKB) combines information on size of technological activities with the relatedness of technological activities across sectors. The higher the index, the higher the patent output in this region and the closer the cognitive proximity between technological activities of different sectors within the region.

\section{Estimation results}

The results of specification (1) indicate that the specialization of technological activities of a region within a particular sector (RTA) has a positive effect ${ }^{10}$ on the extent of foreign technological activities (FAGI) within that region and sector (see Table 2). This is in line with our theoretical proposition as well as earlier findings for European countries (Verspagen and Schoenmakers, 2004; Cantwell and Piscitello, 2005). It is important to note that we measured specialization advantages using all patent applications with at least one German investor. Thus, it constitutes an overall specialization effect taking prior technological activities of both foreign and domestic firms within the respective sector into consideration. Attempts to differentiate between domestic and foreign specialization showed, that both are positive but effects related to prior sectoral specialization of foreign technological activity within the region seem to be stronger. However, the procedure to identify ownership of patenting activities applied in this paper, does not account for corporate ownership (see section 3). Therefore, we refrained from further investigating the interactions between foreign and domestic firms at this stage.

Our estimation results show that relatively high number of sectors with a specialization advantage in terms of technological activities in a given region (MLQ) has a significantly negative effect on the total extent of foreign technological activities. This would suggest that (unrelated) diversification of technological activities across sectors of a region has a negative effect on the localization of foreign technological activities.

\footnotetext{
${ }^{10}$ We cannot interpret the absolute size of the coefficients, since we transform our dependent variable from a fractional to an integer count (see chapter 4.1). Thus, we only interpret the direction of an effect. The size of the coefficients is interpreted insofar that a larger coefficient points to a higher importance of this covariate.
} 


\begin{tabular}{|c|c|c|c|}
\hline & (model 1) & (model 2) & (model q3) \\
\hline VARIABLES & FAGI & FAGI & FAGI \\
\hline Specialization (RTA) & $\begin{array}{c}0.3753^{* * *} \\
(0.0187)\end{array}$ & $\begin{array}{c}0.2540^{* * *} \\
(0.0169)\end{array}$ & $\begin{array}{c}0.3858^{* * *} \\
(0.0178)\end{array}$ \\
\hline Diversification (MLQ) & $\begin{array}{c}-1.5149 * * * \\
(0.1047)\end{array}$ & $\begin{array}{l}- \\
-\end{array}$ & $\begin{array}{l}- \\
-\end{array}$ \\
\hline Related variety (RRV) & $\begin{array}{l}- \\
-\end{array}$ & $\begin{array}{c}0.5716 \\
(2.7510)\end{array}$ & $\begin{array}{c}-30.2619 * * * \\
(2.5378)\end{array}$ \\
\hline Quality of knowledge base (QKB) & $\begin{array}{l}- \\
-\end{array}$ & - & $\begin{array}{c}5.2721 * * * \\
(0.3167)\end{array}$ \\
\hline Interaction term (high tech $*$ RTA) & $\begin{array}{c}0.2078 \\
(0.1313)\end{array}$ & $\begin{array}{c}0.3886^{* * *} \\
(0.1455)\end{array}$ & $\begin{array}{c}0.3303^{* *} \\
(0.1322)\end{array}$ \\
\hline Science \& education infrastructure (SEI) & $\begin{array}{c}0.0011 \\
(0.0013)\end{array}$ & $\begin{array}{c}0.0094^{* * *} \\
(0.0013)\end{array}$ & $\begin{array}{c}0.0031^{* *} \\
(0.0012)\end{array}$ \\
\hline Prior cumulative technological activities & $\begin{array}{c}0.0030 * * * \\
(0.0010)\end{array}$ & $\begin{array}{c}0.0043 * * * \\
(0.0012)\end{array}$ & $\begin{array}{c}0.0012 \\
(0.0008)\end{array}$ \\
\hline Human capital endowment (HCE) & $\begin{array}{c}1.0637^{* * *} \\
(0.2538)\end{array}$ & $\begin{array}{c}1.3784^{* * *} \\
(0.2782)\end{array}$ & $\begin{array}{c}0.9242 * * * \\
(0.2382)\end{array}$ \\
\hline Business Tax & $\begin{array}{l}-0.0015 \\
(0.0010)\end{array}$ & $\begin{array}{l}-0.0001 \\
(0.0010)\end{array}$ & $\begin{array}{c}-0.0022^{* *} \\
(0.0009)\end{array}$ \\
\hline Transport infrastructure & $\begin{array}{c}-0.0244^{* * *} \\
(0.0027)\end{array}$ & $\begin{array}{c}-0.0375^{* * *} \\
(0.0032)\end{array}$ & $\begin{array}{c}-0.0237^{* * *} \\
(0.0030)\end{array}$ \\
\hline Healthcare index & $\begin{array}{c}0.1534 * * \\
(0.0778)\end{array}$ & $\begin{array}{c}0.0275 \\
(0.0871)\end{array}$ & $\begin{array}{c}0.1402 * * \\
(0.0742)\end{array}$ \\
\hline Size & $\begin{array}{c}0.1303 * * * \\
(0.0366)\end{array}$ & $\begin{array}{c}0.2079 * * * \\
(0.0438)\end{array}$ & $\begin{array}{l}0.0240^{*} \\
(0.0321)\end{array}$ \\
\hline Capital & $\begin{array}{c}0.3157^{* * *} \\
(0.0459)\end{array}$ & $\begin{array}{c}0.4737 * * * \\
(0.0510)\end{array}$ & $\begin{array}{c}0.1337^{* *} \\
(0.0513)\end{array}$ \\
\hline MLQ neighbor regions & $\begin{array}{c}-0.5127 * * * \\
(0.1288)\end{array}$ & $\begin{array}{l}- \\
-\end{array}$ & $\begin{array}{l}- \\
-\end{array}$ \\
\hline HCE neighbor regions & $\begin{array}{l}-0.0800 \\
(0.5145)\end{array}$ & $\begin{array}{c}0.6499 \\
(0.5544)\end{array}$ & $\begin{array}{c}0.2786 \\
(0.4990)\end{array}$ \\
\hline SEI neighbor regions & $\begin{array}{c}0.0029 \\
(0.0029)\end{array}$ & $\begin{array}{c}0.0129 * * * \\
(0.0030)\end{array}$ & $\begin{array}{c}0.0044 \\
(0.0030)\end{array}$ \\
\hline RRV neighbor regions & $\begin{array}{l}- \\
-\end{array}$ & $\begin{array}{c}22.1274^{* * *} \\
(3.6071)\end{array}$ & $\begin{array}{c}20.5423^{* * *} \\
(5.2875)\end{array}$ \\
\hline QKB neighbor regions & $\begin{array}{l}- \\
-\end{array}$ & - & $\begin{array}{c}0.0219 \\
(0.4711)\end{array}$ \\
\hline Constant & $\begin{array}{l}1.0263^{*} \\
(0.5779)\end{array}$ & $\begin{array}{c}-4.7530 * * * \\
(0.5743)\end{array}$ & $\begin{array}{l}-1.3300 \\
(0.4771)\end{array}$ \\
\hline In alpha & $\begin{array}{c}-2.1338 * * * \\
(0.1141)\end{array}$ & $\begin{array}{c}-1.9195 * * * \\
(0.1094)\end{array}$ & $\begin{array}{c}-2.1851 * * * \\
(0.1175)\end{array}$ \\
\hline Observations & 29282 & 29282 & 29282 \\
\hline Loglikelihood & -44026 & -45018 & -43895 \\
\hline Chi-square & 8298 & 6603 & 88773 \\
\hline P-value Chi & 0 & 0 & 0 \\
\hline
\end{tabular}

Notes: Robust standard errors in parentheses; Significance at level: ${ }^{* *} p<0.01,{ }^{* *} p<0.05, * p<0.1$; Coefficients for sector, federal state and year dummies are omitted in presentation. Variables are not standardized.

Source: OECD REGPAT (Edition January 2012). Own calculations. 
This finding is not in line with earlier findings from European regions (Cantwell and Piscitello, 2005; 2007). Therefore, we employed alternative measures adopted in existing research to capture diversification effects (inverse of the coefficient of variation based on the RTA or the inverse Herfindahl index) but the result remains unchanged (see Annex Table A4).

Our estimation results show that spillovers deriving from the science and education infrastructure of a region (SEI) seem to have a positive effect on foreign technological activities, which corresponds to our theoretical considerations and earlier findings in the empirical literature (Cantwell and Piscitello, 2005; Görg and Strobl, 2003).

In specification (2) we introduce a first measure for related variety of technological activities between sectors of a given region. We find that the regional related variety index (RRV) has no statistically significant effect on the extent of foreign technological activities across German regions. However, specification (3) shows that the interaction term (QKB) of related variety index and overall technological strength of the given region has a statistically significant positive coefficient. The magnitude of the corresponding coefficient is relatively high, indicating that the influence of this index is considerably stronger than that of all other determinants included in the analysis. The coefficient for related variety (RRV) as such turns significantly negative in specification (3). This would imply that related variety on its own has no effect on the localisation of foreign technological activities within German regions. The effect depends from the technological strength of the region and is positive and significant in regions, where related variety is generated by high levels of technological activities across sectors. From a methodological point of view, the results also indicate that the RRV index on its own is of limited explanatory power, since it seems to be 'inflated' for regions characterized by very low overall technological activity.

Specifications (1) to (3) show that the control variables are mostly significant and have the expected sign. A significantly positive coefficient is found for the interaction term RTA and a high-tech dummy (see specification 2 and 3), which suggests that the effect of sectoral specialization advantages in terms of technological activities is stronger in industries with high R\&D intensity. The estimation results show also a positive effect of sector specific human capital and of regions that host a capital of a federal state. The latter seems to indicate the relevance of more 'general' urbanization externalities. In addition, we find a positive effect of comparatively better transport ${ }^{11}$ and healthcare infrastructure across regions. The results also indicate that relatively high regional business taxes do not deter the localization of foreign technological activities. Finally our results indicate that spatial correlation exists. ${ }^{12}$ We find a significantly negative effect of technological diversification of neighbouring regions and significantly positive inter-regional effects for related variety both in terms of RRV and QKB.

\footnotetext{
${ }^{11}$ The negative sign of the coefficient for transport infrastructure indicates that a longer journey time to the next highway has a negative impact on the extent of foreign technological activities.

${ }^{12}$ We exclude the spatial lag of specialization due to high correlation with other variables (see Annex Table A5).
} 


\section{Conclusion}

Whereas we witnessed a surge in investigations of the economic geography of MNEs, most of the existing research on the internationalization of $R \& D$ and innovation focuses on location factors at the national level of analysis. In this literature, geography is considered in terms of home versus host country. However there is an established stream of research that highlighted a geographic hierarchy of foreign technological activities across and within European countries. So far this literature focused upon the interaction between foreign and domestic firms' technological activities and analysed how intra-industry specialization and regional diversification affect the localization of foreign technological activities.

Our paper contributes to this literature with the proposition that regions characterised with a higher degree of related variety of technological activities between sectors are more likely to attract foreign technological activities than others. This hypothesis is motivated by drawing from two theoretical considerations: First, evolutionary economic geography proposes that knowledge exchange between different sectors is higher, if they share a certain cognitive proximity (Boschma, 2005; Nooteboom, 2000; Frenken et al., 2007 etc.). This type of knowledge exchange between sectors is of particular importance with increasing complexity of technologies. Second, from a competence based view of the firm, it has been suggested that firms expand technological competencies in a path dependent manner by experimenting with new technologies in spatially distinct environments that are related to their existing technological profile (Teece et al. 1994a etc). This possibly explains increasing interconnection between firms internationalization, technological diversification and competence creation over time (Cantwell and Piscitello, 2000; 2014 etc.).

We test our hypothesis at the example of the spatial distribution of foreign technological activities across 96 German planning regions between 1996 and 2009. The choice of the Germany seems appropriate, since it attracts most foreign R\&D within the EU27 and at the same time it is characterised by a pronounced pattern of spatial dispersion of foreign R\&D. Our evidence confirms that sectoral specialization of technological activities within a region is a crucial factor that attracts foreign technological activities. The same holds true for potential externalities deriving from science and education infrastructure. However, our results show that diversification of technological activities across sectors of a region shows a significantly negative effect on foreign technological activities. This finding is robust to different measures of diversification and in contrast to existing evidence (Cantwell and Piscitello, 2005). It could signal that regional diversification in terms of unrelated variety of technological activities between sectors is of less importance to foreign MNEs.

At this point, our proposition regarding the importance of related variety calls for attention. In fact, our estimation results show a strong and positive effect of related technological variety on the localization of foreign technological activities. However, this is only the case for regions that are characterized by overall technological strength. This result could be associated with the notion of so called 'higher-order regions', which are more likely to attract a broad range of domestic and foreign innovative activities as large firms and MNEs 
located there will generally try extend their established lines of specialization through intrafirm networks (Cantwell and lammarino, 1998; 2000). However, our evidence would indicate that it is related variety rather than unrelated variety that facilitates corporate technological diversification in such higher-order regions. Thus, foreign actors are attracted by sectoral specialization advantages in areas of relevance to their activities. In addition, they attach a relatively high value to complementarity of capabilities of different but related sectors which allows a recombination of technology facilitated by cognitive proximity.

It should be noted that our findings are based on an empirical approach that combines region and sector specific characteristics with a purely patent based indicator to identify foreign technological activities. In order to advance research on the role of related variety, it would be necessary to scrutinize the interaction of foreign firm specific technological profiles with location specific technological endowment factors. Thereby, location choice could be investigated at the firm level taking into account different technological strategies of international corporations.

\section{References}

ALCACER, J., CHUNG, W. (2007) Location strategies and knowledge spillovers. Management Sciences, 53: 760-776.

ALLISON, P. (2009) Fixed Effects Regression Models, Thousand Oaks (IU): Sage Publications. ALMEIDA, P., KOGUT, B. (1997) The exploration of technological diversity and the geographic localization of innovation, Small Business Economics, 9: 21-31.

ASHEIM, B., GERTLER, M. (2005) Regional Innovation systems and the Geographical Foundations of Innovation. In: Fagerberg, J.; Mowery, D.C.; Nelson, R.R. (eds.): The Oxford Handbook of Innovation, Oxford: Oxford University Press, pp. 291-317.

AUDRETSCH D.B., FELDMAN, M.P. (1996) R\&D spillovers and the geography of innovation and production, American Economic Review, 86(3): 630-640.

AUDRETSCH, D.B., STEPHAN, P.E. (1996) How localized are networks in biotechnology? American Economic Review, 86(3): 641-652.

BASILE, R., BENFRATELLO, L., CASTELLANI, D. (2012) Geoadditive Models for Regional Count Data: An Application to Industrial Location, ERSA conference paper 2012-89, European Regional Science Association (ERSA).

BASILE, R., CASTELLANI, D., ZANFEI, A. (2008) Location choice of multinational firms in Europe: The role of EU cohesion policy, Journal of International Economics, 74(2): 328-340.

BARRIOS, S., GÖRG, H., STROBL, E. (2006) Multinationals' location choice, agglomeration economies and public incentives, International Regional Science Review, 29(1): 81107.

BEUGELSDIJK, S., MUDAMBI, R. (2013) MNEs as border-crossing multi-location enterprises: The role of discontinuities in geographic space, Journal of International Business Studies, suppl. Special Issue: The Multinational in Geographic Space, 44(5): 413-426.

BOSCHMA, R. (2005) Proximity and Innovation: A Critical Assessment, Regional Studies, 39(1): 61-74.

BOSCHMA, R., FRENKEN, K. (2006) Why is economic geography not an evolutionary science? Towards an evolutionary economic geography, Journal of Economic Geography, 6(3): 273-302. 
BOSCHMA, R., FRENKEN, K. (2011) The emerging empirics of evolutionary economic geography, Journal of Economic Geography, 11(2): 295-307.

BRESCHI, S. (2000) The Geography of innovation: a cross sector analysis, Regional Studies, 34(3): 213-229.

BRESCHI, S., LISSONI, F., MALERBA, F. (2003) Knowledge-relatedness in firm technological diversification, Research Policy, 32(1): 69-87.

CANTNER, U., MEDER, A. (2009) Regional Effects on Cooperative Innovation Activities and the Related Variety of Regional Knowledge Bases, Jena Economic Research Papers, $2009-064$.

CANTNER, U., GRAF, H. 2006. The network of innovators in Jena: an application of social network analysis. Research Policy, 35(4): 463-480.

CANTWELL, J.A. (1989) Technological innovations in multinational corporations, Oxford: Blackwell.

CANTWELL, J. A. (1995) The globalization of technology: what remains of the product cycle model? Cambridge Journal of Economics, 19(1): 155-174.

CANTWELL, J. A. (2000) Multinational corporations and the location of technological innovation in the UK regions, Regional Studies, 34(4): 317-332.

CANTWELL, J.A. (2009) Location and the multinational enterprise, Journal of International Business Studies, 40, 35-41.

CANTWELL, J. A., IAMMARINO, S. (1998) MNCs, technological innovation and regional systems in the EU: some evidence in the Italian case, International Journal of the Economics of Business, 5(3): 383-408.

CANTWELL, J.A., IAMMARINO, S. (2000) Multinational Corporations and the location of technological innovation in the UK regions, Regional Studies, 34(4): 317-322.

CANTWELL, J.A., IAMMARINO, S. (2001) EU Regions and Multinational Corporations: Change, stability, and the strengthening of comparative technological advantages, Industrial and Corporate Change, 10(4): 1007-1037.

CANTWELL, J.A., IAMMARINO, S. (2003) Multinational Corporations and European Regional Systems of Innovation, London: Routledge.

CANTWELL, J.A., NOONAN, C. (2002) The regional distribution of technological development: evidence from FDI in Germany. In: Feldman, M.N.; Massard (eds.): Knowledge Spillovers and the Geography of Innovation, Dordrecht: Kluwer, pp. 199-233.

CANTWELL, J.A., PISCITELLO, L. (2000) Accumulating Technological Competence: It's changing impact of corporate diversification and internationalization, Industrial and Corporate Change, 9: 21-51.

CANTWELL, J.A., PISCITELLO, L. (2002) The location of technological activities of MNCs in European regions: The role of spillovers and local competencies, Journal of International Management, 8: $69-96$

CANTWELL, J.A., PISCITELLO, L. (2005) The Recent Location of Foreign owned R\&D activities by large multinational Corporations in European region: The role of spillovers and externalities, Regional Studies, 39(1): 1-16.

CANTWELL, J.A., PISCITELLO, L. (2007) Attraction and deterrence in the location of foreign owned R\&D activities: the role of positive and negative spillovers, International Journal of Technological Learning, Innovation and Development, 1(1): 87-111.

CANTWELL, J.A., PISCITELLO, L. (2014) Historical changes in the determinants of the composition of innovative activity in MNC subunits, Industrial and Corporate Change, 23(3):633-660. 
CANTWELL, J. A., SANTANGELO, G. D. (2002) The new geography of corporate research in information and communications technology, Journal of Evolutionary Economics, 12(1-2):163-197.

CASTELLS, M., HALL, P. (1994) Technopoles of the World: The making of the $21^{\text {st }}$ Century Industrial Complexes, New York: Routledge.

CHANDLER, A.D. (1990) Scale and Scope: the Dynamics of Industrial Capitalism, Cambridge, MA: Harvard University Press.

CHANDLER, A.D., HAGSTRÖM, P., SÖLVELL, Ö. (1998) The Dynamic Firm: The role of technology, strategy, organizations and regions, Oxford and New York: Oxford University Press.

COWAN, R., DAVID, P.A., FORAY, D. (2000) The explicit economics of knowledge codification and tacitness, Industrial and Corporate Change, 9(2): 211-253.

COOKE, P. (1992): Regional Innovation Systems: Competitive Regulation in the New Europe, Geoforum, Vol. 23, pp. 365-382.

CROZET, M., MAYER, T., MUCCHIELLI, J.L. (2004) HOW DO FIRMS AGGLOMERATE? A STUDY OF FDI IN FRANCE, REGIONAL SCIENCE AND URBAN ECONOMICS, 34(1), $27-54$.

DACHS, B., PYKA, A. (2010) What drives the internationalisation of innovation? Evidence from European patent data, Economics of Innovation and New Technology, 19 (1): 71-86.

DEVEREUX, M., GRIFFITH, R., SIMPSON, H. (2007) Firm location decisions, regional grants and agglomeration externalities, Journal of Public Economics, 91(3-4): 413-435.

ECKEY, H-F., KOSFELD, R., TÜRCK, M. (2006) Räumliche Ökonometrie, Wirtschaftswissenschaftliches Studium, 35(19): 548-554.

EDQUIST, C. (2005) Systems of innovation. Perspectives and challenges. In: Fagerberg, J.; Mowery, D.C.; Nelson R.R. (2005) (eds.): The Oxford Handbook of Innovation, Oxford: Oxford University Press, pp. 181-208.

ERKEN, H., KLEIJN, M. (2010) Location factors of international R\&D activities - an econometric approach, Economics of Innovation and New Technology, 19(3): 203232.

FELDMAN, M.P. (1994) The Geography of Innovation, Dordrecht: Kluwer Academic Publishers.

FRENKEN, K., VAN OORT, F.G., VERBURG, T. (2007): Related variety, unrelated variety and regional economic growth, Regional Studies, 41(5): 685-697.

FRIETSCH, R., SCHMOCH, U., NEUHÄUSLER, P., ROTHENGATTER, O. (2010) Transnational Patents - Structures, Trends and Recent Developments, Expertenkommission Forschung und Innovation, Berlin: Studien zum Deutschen Innovationssystem. 9/2010.

FRITSCH, M., SLAVTCHEV, V. (2007) Universities and Innovation in Space, in: Industry and Innovation, Vol. 14 (2), 2007, S. 201-218.

GAUSELMANN, A., MAREK, P. (2012) Regional Determinants of MNE's Location Choice in Transition Economies, Empirica, 39 (4): 487-511.

GÖRG, H., STROBL, E. (2003) Footloose multinationals? The Manchester School, 71(1): 1-19.

GLAESER, E. L., KALLAL, H. D., SCHEINKMAN, J. A., SHLEIFER, A. (1992) Growth in cities, Journal of Political Economy, 100(6): 1126-1152.

GRANSTRAND, O., SJÖLANDER, S., (1992) Internationalisation and diversification of multitechnology corporations. In: Granstrand, O., Hakanson, L., Sjölander, S. (Eds.), Technology Management and International Business: Internationalisation of R\&D and Technology. London: Wiley. 
GRANSTRAND, O., PATEL, P., PAVITT, K. (1997) Multi-technology corporations: why they have 'distributed' rather than 'distinctive' core competencies. California Management Review, 39: 8-25.

GUELLEC, D., VAN POTTELSBERGHE DE LA POTTERIE, B. (2001) The internationalisation of technology analysed with patent data, Research Policy, 30: 1253-1266.

GUELLEC, D., VAN POTTELSBERGHE DE LA POTTERIE, B. (2004) Measuring the internationalisation of the generation of knowledge. An approach based on patent data. In: H. F. Moed; W. Glänzel; Schmoch, U. (eds), Handbook of quantitative science and technology research. The use of publication and patent statistics in studies on S\&T systems, Dordrecht: Kluwer Academic Publishers, pp. 645-662.

HALL, B.H. (2011) The Internationalization of R\&D, UNU-MERIT Working Paper Series, 49. HATZICHRONOGLOU, T. (1997) Revision of the High-Technology Sector and Product Classification, OECD Science, Technology and Industry Working Papers No. 1997/2.

HOWELLS, J. (1990) The location and organization of research and development: New horizons, Research Policy, Vol. 19(2): 133-146.

IWH, DIW, LMU, WU (2013) Internationale FuE-Standorte. In: Studien zum deutschen Innovationssystem, 11/2013.

JACOBS, J. (1969) The economy of cities, New York: Vintage.

JAFFE, A. TRAJTENBERG, M., HENDERSON, R. (1993) Geographical localisation of knowledge spillovers, as evidenced by patent citations, Quarterly Journal of Economics, 58: 577598.

JAFFE, A., TRAJTENBERG, M. (1996) Flows of Knowledge from Universities and Federal Labs: Modelling the Flow of Patent Citations over Time and across Institutional and Geographic Boundaries, NBER Working Paper, no. 5712, Washington: NBER.

JOHNSON, D. (2002) The OECD Technology Concordance (OTC): Patents by Industry of Manufacture and Sector of Use. OECD Science, Technology and Industry Working Papers 2002/05, Paris: OECD Publishing.

KLINE, S.J., ROSENBERG, N. (1986) An overview of innovation. In: R. Landau; N. Rosenberg (eds) The Positive Sum Strategy, New York: National Academy Press.

KOGUT, B., CHANG, S. (1991) Technological capabilities and Japanese FDI in the United States, Review of Economics and Statistics, 73(3): 401-413.

KORTUM, S., PUTNAM, J. (1997) Assigning patents to industries: tests of the Yale technology concordance. Economic Systems Research, 9 (2): 161-176.

LYBBERT, T.J., ZOLAS, N.J. (2014) Getting patents and economic data to speak to each other: An 'Algorithmic Links with Probabilities' approach for joint analyses of patenting and economic activity, Research Policy,43(3): 530-542.

MALECKI, J. (1985) Industrial location and corporate organization in high technology Industries, Economic Geography, 61(4): 345-369.

MAREK, P. (2012) Agglomeration and FDI in East German Knowledge-Intensive Business Services, Economia Politica, 29(3): 343-360.

MARIOTTI, S., PISCITELLO, L., ELIA, S. (2010) Spatial Agglomeration of multinational enterprises: the role of information externalities and knowledge spillovers, Journal of Economic Geography, 10: 519-538.

MARSHALL, A. (1920) Principles of Economics. An introductory volume, 8th edition, London: MacMillan.

MCCANN P. (2011) International business and economic geography: knowledge, time and transactions costs, Journal of Economic Geography, 11(2): 309-317.

MCCANN P., MUDAMBI, R. (2005) Analytical differences in the economics of geography: the case of the multinational firm, Environment and Planning A, Vol. 37: 1857-1876. 
NELSON, R.R. (1993) National Innovation Systems: A Comparative Analysis, Oxford: Oxford University Press.

NELSON R.R., ROSENBERG N. (1999) Science, technological advance and economic growth, in Chandler A.D., Hagström P. and Sölvell Ö. (Eds) The Dynamic Firm: The Role of Technology, Strategy, Organization, and Regions, Oxford and New York: Oxford University Press.

NOOTEBOOM, B. (2000) Learning and Innovation in Organisations and Economies, Oxford: Oxford University Press.

OECD (2009) OECD Patent Statistics Manual, OECD, Paris.

PATEL, P.,K. PAVITT (1991) Large firms in the production of the worlds' technology: an important case of non-globalisation, Journal of International Business Studies, 22(1): $1-21$.

PATEL, P., K. PAVITT (1997) The technological Competences in the World's largest firms: Complex and path dependent, but not much variety, Research Policy, 26: 141-156.

PATEL, P., K. PAVITT (1998) The Wide (and Increasing) Spread of Competences in the World's largest firms: A Challenge to Conventional Wisdom, in: A.D. Chandler, P. Hagström, Ö. Sölvell (eds.) The Dynamic Firm: The role of technology, strategy, organizations and regions, Oxford and New York: Oxford University Press.

Pavitt, K. (1999) Technologies, products and organisation in the innovating firms: what Adam Smith tells us and Joseph Schumpeter doesn't. In: Dow, S.C., Earl, P.E. (Eds.), Economic Organisation and Economic Knowledge: Essays in Honour of Brian Loasby. Cheltenham: Edward Elgar.

PISCITELLO, L. (2000) Relatedness and coherence in technological and product diversification of the world's largest firms, Structural Change and Economic Dynamics, 11:295-315

PISCITELLO, L. (2004) Corporate diversification, coherence and economic performance, Industrial and Corporate Change, Oxford University Press, 13(5): 757-787.

POLANYI, M. (1966) The Tacit Dimension, New York: Anchor Books.

RICHARDSON, G. B. (1972) The Organization of Industry, Economics Journal, 82: 883-896.

ROSENBERG, N., NELSON, R.R. (1996) The roles of universities in the advance of industrial technology. In: R.S. Rosenbloom; W.J. Spencer (eds) Engines of Innovation: US Industrial Research at the End of an Era, Boston (MA): Harvard Business School Press, pp. 87-110.

RUMELT, R.P. (1974) Strategy, Structure and Economic Performance, Cambridge, MA: Harvard University Press.

SAXENIAN, A. (1994) Regional advantage - Culture and competition in Silicon Valley and Route 128, Cambridge (MA.): Cambridge University Press.

SCHMOCH, U.; LAVILLE, F.; PATEL, P.; FRIETSCH, R. (2003) Linking Technology Areas to Industrial Sectors, Final Report to the European Commission, DG Research, Karlsruhe: Fraunhofer ISI, http://ftp.cordis.europa.eu/pub/indicators/docs/ ind report isi ost spru.pdf, (last accessed on January 2015).

SOETE, L. (1987) The impact of technological innovation on international trade patterns: The evidence reconsidered, Research Policy, 16(2-4): 101-130.

TEECE, D. J., PISANO, G. (1994a) The dynamic capabilities of firms: an introduction, Industrial and Corporate Change, 3(3): 537-555.

TEECE, D.J., RUMELT, R., DOSI, G., Winter, S.,G. (1994b) Understanding corporate coherence: theory and evidence, Journal of Economic Behavior and Organization. 23: 1-30.

VERSPAGEN, B., MOERGASTEL, SLABBERS, M. (1994) MERIT concordance tables: IPC-ISIC (Rev. 2) MERIT Research Memorandum 2/94-004, Maastricht: Merit. 
VERSPAGEN, B., SCHOENMAKERS, W. (2004) The spatial dimension of patenting by multinational firms in Europe, Journal of Economic Geography, 4(1): 23-42.

VON HIPPEL, E. (1994) Sticky information and the locus of problem solving: implications for innovation, Management Science, 40: 429-439.

WINKELMANN, R., BOES, S. (2006) Analysis of Microdata, Berlin, Heidelberg: Springer-Verlag.

WINTER, S.G. (1988) On Coase, competence and the corporation, Journal of Law Economics and Organization, 4: 163-180. 


\section{Annex}

Table A1: Original and transformed FAGI, pooled for the observation period 1996-2009

\begin{tabular}{lcc}
\hline & $\begin{array}{c}\text { Original FAGI } \\
\text { (fractional counts) }\end{array}$ & $\begin{array}{c}\text { FAGI transformed } \\
\text { (integers) }\end{array}$ \\
\hline No. of cases & 29,568 & 29,568 \\
Minimum & 0 & 0 \\
Maximum & 215.55 & 216 \\
Mean & 1.84 & 2.54 \\
Variance & 44.02 & 43.42 \\
Skewness & 11.44 & 11.60 \\
\hline
\end{tabular}

Table A2: Results of the Morans I test for spatial correlations of FAGI in neighboring regions; test based on the standardized neighborhood matrix

\begin{tabular}{lrlrr}
\hline Year & Morans I & \multicolumn{1}{l}{$E(I)$} & z-statistics & p-value \\
\hline 1996 & 0.001 & -0.000 & 0.558 & 0.288 \\
1997 & 0.000 & -0.000 & 0.177 & 0.430 \\
1998 & 0.001 & -0.000 & 0.356 & 0.361 \\
1999 & 0.002 & -0.000 & 1.048 & 0.147 \\
2000 & 0.001 & -0.000 & 0.507 & 0.306 \\
2001 & -0.000 & -0.000 & 0.091 & 0.464 \\
2002 & 0.001 & -0.000 & 0.678 & 0.249 \\
2003 & 0.002 & -0.000 & 0.801 & 0.211 \\
2004 & 0.001 & -0.000 & 0.482 & 0.315 \\
2005 & 0.002 & -0.000 & 0.816 & 0.207 \\
2006 & 0.003 & -0.000 & 1.121 & 0.131 \\
2007 & 0.001 & -0.000 & 0.681 & 0.248 \\
2008 & 0.002 & -0.000 & 0.958 & 0.169 \\
2009 & 0.002 & -0.000 & 0.932 & 0.176 \\
\hline
\end{tabular}

Notes: Due to capacity restrictions of STATA, the test cannot be applied to pooled data and is therefore executed for yearly data.

Test results on the basis of the weighting matrix based on Euclidian distances between the regional capitals are very similar, and are therefore omitted. 
Table A3: Variables used in the binomial regression model

\begin{tabular}{|c|c|c|}
\hline Variable & Measurement & Source \\
\hline \multicolumn{3}{|l|}{ Dependent variable } \\
\hline $\begin{array}{l}\text { Foreign technological } \\
\text { activities (FAGI) }\end{array}$ & $\begin{array}{l}\text { Number of patent applications with at least one } \\
\text { foreign applicant and at least one German inventor } \\
\text { per planning region and sector (NACE Rev. 1.1, 2- } \\
\text { digit level) and year }\end{array}$ & $\begin{array}{l}\text { OECD RegPat database; } \\
\text { own calculations }\end{array}$ \\
\hline \multicolumn{3}{|l|}{ Key explanatory variables } \\
\hline Related variety (RRV) & See chapter 4.2 & $\begin{array}{l}\text { OECD RegPat database; } \\
\text { own calculations }\end{array}$ \\
\hline Related variety (QKB) & See chapter 4.2 & $\begin{array}{l}\text { OECD RegPat database; } \\
\text { own calculations }\end{array}$ \\
\hline Specialization (RTA) & $\begin{array}{l}\text { Revealed technological advantage (RTA) Index of } \\
\text { region, sector and year (basis: all patent applications } \\
\text { with at least one German inventor) }\end{array}$ & $\begin{array}{l}\text { OECD RegPat database; } \\
\text { own calculations }\end{array}$ \\
\hline Diversification (MLQ) & $\begin{array}{l}\text { Median location quotient (basis: all patent } \\
\text { applications with at least one German inventor) }\end{array}$ & $\begin{array}{l}\text { OECD RegPat database; } \\
\text { own calculations }\end{array}$ \\
\hline $\begin{array}{l}\text { Science \& education } \\
\text { infrastructure (SEI) }\end{array}$ & $\begin{array}{l}\text { Number of students in higher education per 1,000 } \\
\text { inhabitants of the region }\end{array}$ & INKAR database \\
\hline \multicolumn{3}{|l|}{ Control Variables } \\
\hline High Tech*RTA index & $\begin{array}{l}\text { Interaction term of RTA index with a dummy for } \\
\text { high-tech industries }\end{array}$ & $\begin{array}{l}\text { OECD RegPat database; } \\
\text { own calculations }\end{array}$ \\
\hline Cumulative causation & $\begin{array}{l}\text { Cumulative prior number of all patent applications } \\
\text { (with at least one German inventor) }\end{array}$ & $\begin{array}{l}\text { OECD RegPat database; } \\
\text { own calculations }\end{array}$ \\
\hline $\begin{array}{l}\text { Human capital endowment } \\
\text { (HCE) }\end{array}$ & $\begin{array}{l}\text { Share of highly qualified employees in the total } \\
\text { number of employees with sector specific } \\
\text { qualification in the region }\end{array}$ & INKAR database \\
\hline Business tax & Business tax rate of the region & INKAR database \\
\hline Transport infrastructure & Journey time by car to the next motorway & INKAR database \\
\hline Healthcare index & $\begin{array}{l}\text { Number of doctors and hospital beds related to the } \\
\text { number of inhabitants per region }\end{array}$ & INKAR database \\
\hline Size & Log size of region in square kilometres & INKAR database \\
\hline Capital & Dummy for the capital (federal state) in the region & own calculations \\
\hline SEI neighbor regions & Average SEI of neighboring regions & INKAR database \\
\hline HCE neighbor regions & Average HCE of neighboring regions & INKAR database \\
\hline MLQ neighbor regions & $\begin{array}{l}\text { Average MLQ (basis: all patent applications) of } \\
\text { neighboring regions }\end{array}$ & INKAR database \\
\hline Sector & $\begin{array}{l}\text { Dummies for NACE Rev. } 1.12 \text { digit level NACE 15-35 } \\
\text { (NACE } 36 \text { as reference) }\end{array}$ & own calculations \\
\hline Federal states & $\begin{array}{l}\text { Dummies for } 16 \text { Federal States (reference: } \\
\text { Mecklenburg-Vorpommern) }\end{array}$ & own calculations \\
\hline Year & Annual dummies 1997 - 2009 (reference: 1996) & own calculations \\
\hline
\end{tabular}

Note: All variables are available yearly; dependent variable: 1996-2009; explanatory variables 1995-2008. INKAR database = Indicators and maps on spatial development in Germany and Europe (provided by the Federal Institute for Research on Building, Urban Affairs and Spatial Development, Germany) 
Table A4: Robustness check of the estimation results

\begin{tabular}{|c|c|c|c|c|c|c|}
\hline \multirow[b]{2}{*}{ VARIABLES } & \multicolumn{4}{|c|}{ Robustness check (Model 3) } & \multicolumn{2}{|c|}{$\begin{array}{l}\text { Alternative definitions of } \\
\text { diversification (Model 1) }\end{array}$} \\
\hline & $\begin{array}{l}\text { Inflated } \\
\text { NegBin } \\
\text { FAGI }\end{array}$ & $\begin{array}{l}\text { Tobit } \\
\text { FAGI }\end{array}$ & $\begin{array}{c}\text { Fixed Effects } \\
\text { FAGI }\end{array}$ & $\begin{array}{c}\text { 5-year } \\
\text { lagged cov. } \\
\text { FAGI }\end{array}$ & $\begin{array}{c}\text { Inv. Variation } \\
\text { coefficient } \\
\text { FAGI }\end{array}$ & $\begin{array}{c}\text { Herfindahl } \\
\text { index (Inv.) } \\
\text { FAGI }\end{array}$ \\
\hline Specialization (RTA) & $\begin{array}{l}0.3827 * * * \\
(0.009)\end{array}$ & $\begin{array}{c}0.4091^{* *} \\
(0.175)\end{array}$ & $\begin{array}{c}0.0640 * * * \\
(0.015)\end{array}$ & $\begin{array}{c}0.4015^{* * *} \\
(0.017)\end{array}$ & $\begin{array}{l}0.2472^{* * *} \\
(0.017)\end{array}$ & $\begin{array}{c}0.2585 * * * \\
(0.017)\end{array}$ \\
\hline Interaction term (high tech * RTA) & $\begin{array}{c}0.3302 * * * \\
(0.021)\end{array}$ & $\begin{array}{l}2.0964 \\
(2.130)\end{array}$ & $\begin{array}{c}0.6504 * * * \\
(0.035)\end{array}$ & $\begin{array}{c}0.2362^{*} \\
(0.122)\end{array}$ & $\begin{array}{c}0.4352^{* * *} \\
(0.145)\end{array}$ & $\begin{array}{c}0.3862 * * * \\
(0.147)\end{array}$ \\
\hline Diversification & $\begin{array}{l}- \\
-\end{array}$ & - & - & - & $\begin{array}{c}-0.0713 * * * \\
(0.013)\end{array}$ & $\begin{array}{l}-0.4371 \\
(1.478)\end{array}$ \\
\hline Related variety (RRV) & $\begin{array}{c}-30.2591 * * * \\
(0.887)\end{array}$ & $\begin{array}{c}-27.9721^{*} \\
(16.358)\end{array}$ & $\begin{array}{c}-7.6367 * * * \\
(1.161)\end{array}$ & $\begin{array}{c}-30.6344 * * * \\
(2.318)\end{array}$ & $\begin{array}{l}- \\
-\end{array}$ & - \\
\hline Quality of knowledge base (QKB) & $\begin{array}{l}5.2713^{* * *} \\
(0.109)\end{array}$ & $\begin{array}{l}4.3258 \\
(3.030)\end{array}$ & $\begin{array}{l}2.6495^{* * *} \\
(0.185)\end{array}$ & $\begin{array}{c}4.9951^{* * *} \\
(0.267)\end{array}$ & $\begin{array}{l}- \\
-\end{array}$ & - \\
\hline $\begin{array}{l}\text { Science \& education infrastructure } \\
\text { (SEI) }\end{array}$ & $\begin{array}{c}0.0031 * * * \\
(0.001)\end{array}$ & $\begin{array}{l}0.0018 \\
(0.005)\end{array}$ & $\begin{array}{r}-0.0003 \\
(0.001)\end{array}$ & $\begin{array}{l}0.0059 * * * \\
(0.001)\end{array}$ & $\begin{array}{c}0.0090^{* * *} \\
(0.001)\end{array}$ & $\begin{array}{c}0.0080^{* * *} \\
(0.001)\end{array}$ \\
\hline Prior cumulative techn. activities & $\begin{array}{c}0.0012^{* * *} \\
(0.000)\end{array}$ & $\begin{array}{c}0.1210 * * * \\
(0.026)\end{array}$ & $\begin{array}{l}0.0034 * * * \\
(0.000)\end{array}$ & $\begin{array}{l}0.0012 \\
(0.001)\end{array}$ & $\begin{array}{c}0.0038^{* * *} \\
(0.001)\end{array}$ & $\begin{array}{c}0.0044 * * * \\
(0.001)\end{array}$ \\
\hline Human capital endowment (HCE) & $\begin{array}{c}0.9241 * * * \\
(0.073)\end{array}$ & $\begin{array}{c}5.0026 * * * \\
(1.828)\end{array}$ & $\begin{array}{c}0.7890 * * * \\
(0.135)\end{array}$ & $\begin{array}{c}1.0579 * * * \\
(0.280)\end{array}$ & $\begin{array}{c}1.3186^{* * *} \\
(0.270)\end{array}$ & $\begin{array}{c}1.3331^{* * *} \\
(0.277)\end{array}$ \\
\hline Business Tax & $\begin{array}{c}-0.0022^{* * *} \\
(0.000)\end{array}$ & $\begin{array}{c}-0.0075^{*} \\
(0.004)\end{array}$ & $\begin{array}{l}0.0004 \\
(0.000)\end{array}$ & $\begin{array}{c}-0.0030 * * * \\
(0.001)\end{array}$ & $\begin{array}{l}0.0004 \\
(0.001)\end{array}$ & $\begin{array}{l}0.0001 \\
(0.001)\end{array}$ \\
\hline Transport infrastructure & $\begin{array}{c}-0.0237 * * * \\
(0.001)\end{array}$ & $\begin{array}{c}-0.0488 * * * \\
(0.013)\end{array}$ & $\begin{array}{c}-0.0210 * * * \\
(0.003)\end{array}$ & $\begin{array}{c}-0.0261^{* * *} \\
(0.003)\end{array}$ & $\begin{array}{c}-0.0321 * * * \\
(0.003)\end{array}$ & $\begin{array}{c}-0.0349 * * * \\
(0.003)\end{array}$ \\
\hline Healthcare index & $\begin{array}{c}0.1402^{* * *} \\
(0.030)\end{array}$ & $\begin{array}{l}0.7012 \\
(0.438)\end{array}$ & $\begin{array}{c}-0.1407^{* *} \\
(0.055)\end{array}$ & $\begin{array}{l}0.1329 \\
(0.082)\end{array}$ & $\begin{array}{l}0.0718 \\
(0.083)\end{array}$ & $\begin{array}{l}0.0697 \\
(0.080)\end{array}$ \\
\hline Size & $\begin{array}{l}0.0240 \\
(0.015)\end{array}$ & $\begin{array}{l}0.1139 \\
(0.116)\end{array}$ & $\begin{array}{r}-0.0235 \\
(0.017)\end{array}$ & $\begin{array}{l}0.0573 \\
(0.037)\end{array}$ & $\begin{array}{c}0.2840 * * * \\
(0.047)\end{array}$ & $\begin{array}{c}0.2782^{* * *} \\
(0.047)\end{array}$ \\
\hline Capital & $\begin{array}{c}0.1337 * * * \\
(0.018)\end{array}$ & $\begin{array}{c}0.6973 * * \\
(0.286)\end{array}$ & - & $\begin{array}{c}0.1693 * * * \\
(0.051)\end{array}$ & $\begin{array}{c}0.4403 * * * \\
(0.050)\end{array}$ & $\begin{array}{c}0.4581 * * * \\
(0.050)\end{array}$ \\
\hline Diversification neighbor regions & $\begin{array}{l}- \\
-\end{array}$ & - & $\begin{array}{l}- \\
-\end{array}$ & $\begin{array}{l}- \\
-\end{array}$ & $\begin{array}{c}-1.0733^{* * *} \\
(0.152)\end{array}$ & $\begin{array}{c}-0.9616^{* * *} \\
(0.151)\end{array}$ \\
\hline RRV neighbor regions & $\begin{array}{c}20.5413^{* * *} \\
(1.845)\end{array}$ & $\begin{array}{c}64.5268 * * \\
(26.838)\end{array}$ & $\begin{array}{l}-3.0723 \\
(1.953)\end{array}$ & $\begin{array}{c}11.2216^{* *} \\
(5.223)\end{array}$ & $\begin{array}{l}- \\
-\end{array}$ & $\begin{array}{l}- \\
-\end{array}$ \\
\hline QKB neighbor regions & $\begin{array}{l}0.0223 \\
(0.188)\end{array}$ & $\begin{array}{l}-1.3777 \\
(1.700)\end{array}$ & $\begin{array}{c}1.5852^{* * *} \\
(0.228)\end{array}$ & $\begin{array}{l}0.4033 \\
(0.528)\end{array}$ & - & - \\
\hline HCE neighbor regions & $\begin{array}{c}0.2788^{*} \\
(0.166)\end{array}$ & $\begin{array}{r}-0.0620 \\
(2.622)\end{array}$ & $\begin{array}{c}2.0574^{* * * *} \\
(0.256)\end{array}$ & $\begin{array}{l}0.3986 \\
(0.591)\end{array}$ & $\begin{array}{l}0.3707 \\
(0.535)\end{array}$ & $\begin{array}{l}0.2685 \\
(0.552)\end{array}$ \\
\hline SEI neighbor regions & $\begin{array}{c}0.0044 * * * \\
(0.001)\end{array}$ & $\begin{array}{c}0.0179 * \\
(0.010)\end{array}$ & $\begin{array}{l}0.0008 \\
(0.002)\end{array}$ & $\begin{array}{c}0.0078^{* *} \\
(0.003)\end{array}$ & $\begin{array}{l}0.0038 \\
(0.003)\end{array}$ & $\begin{array}{c}0.0062^{* *} \\
(0.003)\end{array}$ \\
\hline Constant & $\begin{array}{c}-1.3306^{* * *} \\
(0.235)\end{array}$ & $\begin{array}{c}-3.9899 * * \\
(1.951)\end{array}$ & $\begin{array}{r}-0.2123 \\
(0.282)\end{array}$ & $\begin{array}{r}-0.3573 \\
(0.480)\end{array}$ & $\begin{array}{c}-1.9763 * * * \\
(0.592)\end{array}$ & $\begin{array}{c}-2.0677^{* * *} \\
(0.589)\end{array}$ \\
\hline In alpha & $\begin{array}{c}-2.1850 * * * \\
(0.024)\end{array}$ & $\begin{array}{l}- \\
-\end{array}$ & - & $\begin{array}{c}-2.0475 * * * \\
(0.135)\end{array}$ & $\begin{array}{c}-1.9542 * * * \\
(0.107)\end{array}$ & $\begin{array}{c}-1.9160^{* * *} \\
(0.111)\end{array}$ \\
\hline sigma & $\begin{array}{l}- \\
- \\
- \\
-\end{array}$ & $\begin{array}{c}4.8023 * * * \\
(0.796) \\
- \\
-\end{array}$ & $\begin{array}{l}- \\
- \\
- \\
-\end{array}$ & $\begin{array}{l}- \\
- \\
- \\
-\end{array}$ & $\begin{array}{l}- \\
- \\
- \\
-\end{array}$ & $\begin{array}{l}- \\
- \\
-\end{array}$ \\
\hline Region & $\begin{array}{c}-0.0042 \\
(14155.215)\end{array}$ & $\begin{array}{l}- \\
-\end{array}$ & $\begin{array}{l}- \\
-\end{array}$ & $\begin{array}{l}- \\
-\end{array}$ & $\begin{array}{l}- \\
-\end{array}$ & $\begin{array}{l}- \\
-\end{array}$ \\
\hline Sector & $\begin{array}{c}0.0042 \\
(523753.41)\end{array}$ & $\begin{array}{l}- \\
-\end{array}$ & $\begin{array}{l}- \\
-\end{array}$ & $\begin{array}{l}- \\
-\end{array}$ & $\begin{array}{l}- \\
-\end{array}$ & $\begin{array}{l}- \\
-\end{array}$ \\
\hline Constant inflation model & $\begin{array}{c}-38.1888 \\
(14673829.6) \\
\end{array}$ & $\begin{array}{l}- \\
- \\
\end{array}$ & $\begin{array}{l}- \\
- \\
\end{array}$ & $\begin{array}{l}- \\
-\end{array}$ & $\begin{array}{l}- \\
-\end{array}$ & $\begin{array}{l}- \\
- \\
\end{array}$ \\
\hline Observations & 29282 & 29282 & 29282 & 20834 & 29282 & 29282 \\
\hline Loglikelihood & -43895 & -87496 & - & -32418 & -44906 & -45019 \\
\hline Chi-square / F-test & 35595 & 24.18 & 2508 & 8433 & 6663 & 6656 \\
\hline P-value Chi-square / F-test & 0 & 0 & 0 & 0 & 0 & 0 \\
\hline Vuongtest & -0.457 & - & - & - & - & - \\
\hline P-value Vuongtest & 0.6763 & - & - & - & - & - \\
\hline
\end{tabular}

Notes: Standard errors in parentheses; Significance level: ${ }^{* *} p<0.01,{ }^{* *} p<0.05,{ }^{*} p<0.1$; Coefficients for sector, federal state and year dummies omitted. Source: OECD REGPAT (Edition January 2012). Own calculations. 
Table A5: Correlation matrix

\begin{tabular}{|c|c|c|c|c|c|c|c|c|c|c|c|c|c|c|c|c|c|c|c|c|}
\hline & 1 & 2 & 3 & 4 & 5 & 6 & 7 & 8 & 9 & 10 & 11 & 12 & 13 & 14 & 15 & 16 & 17 & 18 & 19 & 20 \\
\hline 1 & 1 & & & & & & & & & & & & & & & & & & & \\
\hline 2 & -0.0568 & 1 & & & & & & & & & & & & & & & & & & \\
\hline 3 & 0,4889 & -0.1917 & 1 & & & & & & & & & & & & & & & & & \\
\hline 4 & $-0,3051$ & 0.4489 & -0.0839 & 1 & & & & & & & & & & & & & & & & \\
\hline 5 & 0,1418 & -0.1547 & 0.0675 & -0.3642 & 1 & & & & & & & & & & & & & & & \\
\hline 6 & 0,3606 & -0.4205 & 0.0932 & -0.8785 & 0.6277 & 1 & & & & & & & & & & & & & & \\
\hline 7 & 0,1161 & -0.1761 & 0.0311 & -0.3901 & 0.1325 & 0.3442 & 1 & & & & & & & & & & & & & \\
\hline 8 & 0,8673 & -0.0515 & 0.4062 & -0.2601 & 0.1239 & 0.3258 & 0.1068 & 1 & & & & & & & & & & & & \\
\hline 9 & 0,3036 & -0.1254 & 0.4140 & -0.0993 & 0.0651 & 0.1078 & 0.1189 & 0.2897 & 1 & & & & & & & & & & & \\
\hline 10 & 0,1117 & -0.1829 & 0.0206 & -0.3596 & -0.0828 & 0.2844 & 0.4587 & 0.1180 & 0.0716 & 1 & & & & & & & & & & \\
\hline 11 & $-0,1388$ & 0.2015 & -0.0281 & 0.4041 & 0.0035 & -0.3361 & -0.1995 & -0.1187 & -0.0200 & -0.4324 & 1 & & & & & & & & & \\
\hline 12 & 0,0491 & -0.0645 & 0.0171 & -0.1304 & 0.0826 & 0.1292 & 0.3846 & 0.0425 & 0.0722 & 0.0210 & -0.0656 & 1 & & & & & & & & \\
\hline 13 & $-0,0156$ & 0.0929 & -0.0110 & 0.1659 & 0.0807 & -0.0923 & -0.2596 & -0.0123 & -0.0459 & -0.5075 & 0.3426 & -0.1127 & 1 & & & & & & & \\
\hline 14 & 0,1855 & -0.0834 & 0.0155 & -0.2257 & 0.1040 & 0.2372 & 0.3227 & 0.1614 & 0.1729 & 0.2347 & -0.2259 & 0.1578 & -0.1443 & 1 & & & & & & \\
\hline 15 & $-0,1336$ & 0.7425 & -0.3044 & 0.2768 & -0.0684 & -0.2605 & -0.0325 & -0.1131 & -0.1675 & -0.1200 & 0.1150 & -0.0265 & 0.0837 & 0.0881 & 1 & & & & & \\
\hline 16 & $-0,1731$ & 0.3178 & -0.0567 & 0.5959 & -0.1910 & -0.5723 & -0.0428 & -0.1579 & 0.0448 & -0.2176 & 0.2096 & -0.0189 & 0.1409 & 0.1675 & 0.4451 & 1 & & & & \\
\hline 17 & 0,1078 & -0.0951 & 0.0333 & -0.2183 & 0.3431 & 0.3509 & -0.1591 & 0.1177 & -0.0094 & -0.2491 & 0.1769 & 0.1612 & 0.2247 & -0.1632 & -0.1573 & -0.4332 & 1 & & & \\
\hline 18 & 0,1773 & -0.2864 & 0.0574 & -0.5464 & 0.2789 & 0.6093 & -0.0013 & 0.1892 & -0.0415 & 0.1319 & -0.1165 & 0.0925 & -0.0622 & -0.2093 & -0.4050 & -0.9059 & 0.6667 & 1 & & \\
\hline 19 & 0,2182 & -0.2260 & 0.5552 & 0.0212 & 0.0194 & -0.0181 & -0.0517 & 0.2085 & 0.4783 & -0.0523 & 0.0849 & 0.0086 & 0.0593 & -0.0085 & -0.2680 & -0.0040 & 0.0834 & 0.0275 & 1 & \\
\hline 20 & 0,0302 & -0.0884 & 0.0065 & -0.1361 & -0.0607 & 0.1088 & -0.1679 & 0.0539 & -0.0699 & 0.3080 & -0.2103 & -0.2874 & 0.0387 & -0.2080 & -0.1936 & -0.4542 & 0.0648 & 0.3523 & 0.0244 & 1 \\
\hline
\end{tabular}

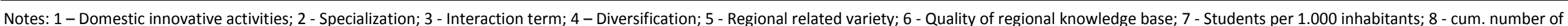
patents; 9 - Share of highly qualified employees; 10 - Business tax; 11 - Journey time to next motorway; 12 - Health index; 13 - Size; 14 - State capital region; 15 - Specialization (neighbor regions); 16 - Diversification (neighbor regions); 17 - Regional related variety (neighbor regions); 18 - Quality of knowledge base (neighbor regions); 19 - Share of highly qualified employees (neighbor regions); 20 - Students per 1.000 inhabitants (neighbor regions).

Source: OECD REGPAT (Edition January 2012). Own calculations. 